\title{
The drivers of the post-entry internationalisation commitment of small and medium-sized enterprises
}

\author{
Nadia Zahoor \\ (First author, E-mail: nadia.zahoor@strath.ac.uk) \\ Lecturer and Chancellor's Fellow \\ Hunter Centre for Entrepreneurship, University of Strathclyde \\ 199 Cathedral Street, Glasgow, G4 0QU, United Kingdom \\ Yong Kyu Lew \\ (Corresponding author, E-mail: yklew@hufs.ac.kr) \\ Professor of International Business \\ College of Business, Hankuk University of Foreign Studies \\ 107, Imun-ro, Dongdaemun-gu, Seoul, 02450, South Korea
}

\begin{abstract}
By integrating relational embeddedness in international strategic alliance networks (ISANs) and the dynamic capability perspective, this article presents an examination of the drivers of the post-entry internationalisation commitment of small and medium sized enterprises (SMEs). Specifically, we investigated the mediating effect of opportunity-sensing capabilities (OSCs) on the relationship between ISAN relational embeddedness and post-entry internationalisation commitment of SMEs. We also examined the moderating impact of strategic adaptiveness on the relationship between OSCs and post-entry internationalisation commitment. An analysis of 320 UK-based SMEs, performed using structural equation modelling, revealed that OSCs are an important mechanism through which the ISAN relational embeddedness leads to increased post-entry internationalisation commitment. Furthermore, strategic adaptiveness strengthens the positive relationship between OSCs and post-entry commitment to foreign markets. This article extends the existing SME venturing and internationalisation literature to the domain of SME post-entry internationalisation commitment.
\end{abstract}

Keywords: Relational embeddedness; opportunity-sensing capabilities; strategic adaptiveness; post-entry internationalisation commitment; SME. 


\section{Introduction}

The international entrepreneurship literature highlights the importance of internationalising small and medium-sized enterprises (SMEs) in driving economic growth (Gerschewski et al., 2018; Riviere and Suder, 2016). Accordingly, the strategies used by such SMEs have been attracting interest (Knight and Liesch, 2016; Safari and Chetty, 2019). In this regard, while most SME research is focussed on the pre-internationalisation stage, and analyses why and how SMEs internationalise from their inception (Petrou et al., 2020; Cavusgil and Knight, 2015), "less is known about continued SME internationalization after this point" (Hilmersson and Johanson, 2016: 68). As such, SME post-entry internationalisation commitmentreferring to the resources allocated to foreign markets after initial market entry (Putzhammer et al., 2018) - has been relatively neglected. Investigating post-entry commitment is crucial because those SMEs that promptly commit resources to international markets can gain a platform suited to develop relationships, access new markets, and promote learning (Chetty et al., 2014; Sleuwaegen and Onkelinx, 2014). However, the complexity and magnitude of the heterogeneous resources required for post-entry internationalisation commitment may be a challenge for small and resource-constrained SMEs (Puthusserry et al., 2020b). Yet, many SMEs do commit to foreign markets, competing with established firms during the post-entry phase (Khan and Lew, 2018).

Prior studies highlight the role played by international strategic alliance networks (ISANs) - i.e., networks of "voluntary arrangements between firms involving exchange, sharing, or co-development of products, technologies, or services" (Gulati, 1998: 293)1_ within which SMEs are engaged in foreign markets. Being part of ISANs is a critical strategic option for the international venturing journey of SMEs, which have limited resources and knowledge for foreign market entry and expansion (Fernhaber and Li, 2013; Stoian et al., 2018). ISANs can specifically facilitate the post-entry internationalisation commitment of SMEs as they assist in accessing the complementary knowledge possessed by partners, and reduce the cost of international venturing (Martineau and Pastoriza, 2016; Gerschewski et al., 2018; Hughes et al., 2019) by overcoming the liabilities of foreignness and newness (Fernhaber and Li, 2013). ISANs, however, present SMEs with considerable risks given the transaction costs involved and the unpredictability of their partners' opportunistic behaviours

\footnotetext{
${ }^{1}$ Such non-equity based international strategic alliances are "the emerging form of network collaboration within the internationalization process [between two or more] firms" (Lew et al., 2013: 1103), "involving cross-border flows and linkages that utilize resources and/or governance structure" (Parkhe, 1991: 581). Thus, voluntary ISAN members strive to achieve "competitive advantage for the partners" (Das and Teng, 2000: 33).
} 
(Gao et al., 2016; Lew et al., 2013). Thus, another stream of the alliance literature focusses on the role played by relational capital in ISANs, as the risks inherent in foreign relationships may be mitigated by favouring familiar partners and strong relational ties (Catanzaro et al., 2019; Dimitratos et al., 2016).

In particular, relational embeddedness - which refers to the "actual and potential resources embedded with, available through, and derived from the network of relationships possessed by an individual or a social unit" (Nahapiet and Ghoshal, 1998: 243) -is an important governance mechanism in ISANs. It denotes the quality of the interpersonal relationships that develop between ISAN actors due to their ongoing interaction (Bermiss and Greenbaum, 2016; Dong et al., 2015). Thus, being part of a tight knit ISAN may mitigate the risk inherent in international alliances. For example, through information exchange, ISAN relational embeddedness encourages partners to participate in knowledge creation, thus promoting social interaction and enhancing value creation (Ebers and Maurer, 2014; SanzBlas et al., 2021; Zhang et al., 2018). Furthermore, the regular exchange of foreign market knowledge found in tight knit ISANs can enhance SMEs' post-entry resource commitment to foreign markets (Vahlne and Johanson, 2013). However, the extant scholarly work has largely focussed on ISAN relational embeddedness in the context of multinational enterprises (MNEs) (Figueiredo, 2011; Oehmichen and Puck, 2016) with few studies dedicated to internationally venturing SMEs (Masiello and Izzo, 2019). SME internationalisation differs from that of MNEs in several ways, including organisational architecture (e.g., structure, decision-making, culture, and control) and the availability of resources and knowledge pools (Dimitratos et al., 2016; Dasí et al., 2015; Deschryvere, 2014). For example, due to their lesser international diversification and foreign engagement, SMEs lack foreign market knowledge (Knight and Liesch, 2016). Such differences force SMEs to exploit their ISAN relational embeddedness for post-entry internationalisation commitment (see Coviello and Cox, 2006); accordingly, this was the focus of our study.

In our research, we developed an integrative conceptual framework by building on ISAN relational embeddedness and the dynamic capability perspective on the firm. Particularly, ISAN relational embeddedness (Uzzi, 1997; Tsai and Ghoshal, 1998) may provide SMEs with potential opportunities — such as information and knowledge access - for their post-entry internationalisation commitment. As such, to convert the potential benefits of network relationships (e.g., international alliances) into realised international venture performance, SMEs need to develop their opportunity-sensing dynamic capabilities (Teece, 2007; Vahlne and Johanson, 2013). In other words, SMEs should develop the important 
dynamic capability to sense and identify opportunities in their search for technological and market knowledge (Teece, 2007; Teece et al., 1997).

Post-entry internationalisation is a risky venturing process that requires up-to-date market information and specialised knowledge (Khan and Lew, 2018). The failure to properly exploit the critical knowledge found in external relationships may limit the ability of SMEs to achieve post-entry internationalisation commitment in highly volatile environments and global landscapes. Therefore, opportunity-sensing capabilities (OSCs) could be essential for SMEs to convert the potential benefits of ISAN relational embeddedness into realised postentry internationalisation commitment (Gerschewski, 2021; Ren et al., 2021)—which mere information sharing cannot guarantee-by enabling them to identify opportunities and renew their competencies in order to align their offerings with the demands of dynamic international markets (Teece, 2014b).

In addition, we posited that OSCs and post-entry internationalisation commitment relationships are contingent on strategic adaptiveness, which refers to the ability of SMEs to adapt their upstream technological and downstream marketing practices to foreign market idiosyncrasies (Hollender et al., 2017). Strategic adaptiveness creates value for SMEs, as customizing their foreign market offerings helps them to better position their products in such markets and, in turn, represents a major source of competitive advantage (Domurath et al., 2020; Fariborzi and Keyhani, 2018). Therefore, the possession of greater strategic adaptiveness enables SMEs to better exploit their OSCs to attain post-entry internationalisation commitment (Puthusserry et al., 2020b).

Based on the issues addressed above, we formulated the following research questions: "To what extent does ISAN relational embeddedness affect the OSCS and SME post-entry internationalisation commitment?" and "How does strategic adaptiveness moderate the relationship between OSCS and SME post-entry internationalisation commitment?" To answer these questions, we conducted a survey involving 320 UK-based SMEs from different manufacturing sectors and analysed the data using structural equation modelling.

Our study makes two important contributions to the SME literature. First, the extant literature largely focussed on the pre-internationalisation stage (cf. Zahoor et al., 2020), neglecting the post-entry one (Puthusserry et al., 2020b; Khan and Lew, 2018). Scholars therefore called for more research on the determinants of internationalisation commitment in the post-entry stage (Ibeh et al., 2018; Puthusserry et al., 2020a). In our endeavour, we highlighted the role played by the social aspect of ISAN in facilitating the post-entry internationalisation commitment of SMEs and empirically examined their relationships. Our 
study thus provides a deeper understanding of SME post-entry internationalisation by considering the social structures of ISANs. In doing so, our study considered the role played by ISAN relational embeddedness - as social structures - to promote the post-entry internationalisation commitment of SMEs.

Second, our study demonstrates that ISAN relational embeddedness does not directly lead to post-entry internationalisation commitment. It conceptually employs OSCs as a mediating mechanism to associate ISAN relational embeddedness with effective post-entry internationalisation commitment. Furthermore, our conceptual model considers the moderating role played by the strategic adaptiveness of SMEs in the relationship between their OSCs and post-entry internationalisation commitment. The validated model shows that, through their OSCs and strategic adaptiveness, SMEs mitigate their lack of knowledge of foreign markets and of sensitivity to international market challenges without overstretching their limited resources. Therefore, from the social (i.e., ISAN relational embeddedness), strategic (i.e., OSCs) and contingent (i.e., strategic adaptiveness) perspectives of SME internationalisation, our research extends the existing SME internationalisation literature to the domain of post-entry internationalisation commitment.

\section{Literature review}

\section{ISAN relational embeddedness}

Embeddedness focusses on the closeness whereby actors become more socially attached to their relationships over time, altering the characteristics of their exchange relationships from arm's length transactions towards trust and producing mutually beneficial relationships (Uzzi, 1997). However, most of the international business literature related to embeddedness is focussed on the MNE headquarters-subsidiary context (Oehmichen and Puck, 2016; Nell and Ambos, 2013). Scholars have often argued that subsidiaries are embedded in internal and external relationships to enhance their opportunity development and, ultimately, international growth (Ferraris et al., 2018). For example, within internal embeddedness, subsidiaries develop close relationships with other sub-units and their headquarters, which provides them with access to existing resources and capabilities for business-related needs (Ciabuschi et al., 2014). In contrast, external embeddedness concerns the mutual adaptation between subsidiaries and their business partners (e.g., primarily customers and suppliers) to develop production processes and technological competencies (Oehmichen and Puck, 2016).

Despite the long-acknowledged role played by the multi-level aspect of embeddedness in extensive MNE networks, the SME context seldom receives attention in the 
international alliance literature (Ciabuschi et al., 2014; Ferraris et al., 2018). Prior research suggests that the extent to which ISAN partners share knowledge and promote learning is determined by the strength of their embeddedness (Zhang et al., 2018; Soontornthum et al., 2020). This infers that ISAN embeddedness forces actors away from the pursuit of narrow economic benefits and towards the nurturing of relations through social exchange and mutual adaptation (Frasquet et al., 2018). This indicates the prevalence of the vital underlying construct of 'ISAN relational embeddedness', which refers to the quality of the social linkages in which a firm is involved (Ebers and Maurer, 2014).

ISAN relational embeddedness can provide access to fine-grained information on strategy, production processes, and profit margins, thereby promoting learning and opportunity recognition (Inkpen and Tsang, 2005). This is particularly relevant for internationalising SMEs that, lacking internal resources, often get involved in networks as a countermeasure (Coviello and Cox, 2006). By developing close relationships with international alliance partners, SMEs can access accurate and time-sensitive information and knowledge while minimising the related transaction costs (Masiello et al., 2013). In addition, ISAN relational embeddedness can enable SMEs to develop location-bound and firm-specific advantages (Fraccastoro et al., 2021) and minimise their liability of foreignness, thus broadening the scope of their post-entry internationalisation commitment (Vahlne and Johanson, 2017). Prior studies have modelled ISAN relational embeddedness to investigate its influence on various MNE outcomes, such as knowledge transfer (Ferraris et al., 2018), innovation (Isaac et al., 2019), and international performance (Rugman, 2014). However, to date, the relevance of ISAN relational embeddedness for SMEs is conspicuously missing in the literature (Prashantham and Dhanaraj, 2015). Indeed, due to commonly lacking resources, operational history, and the experience vital to achieving foreign market objectives, SMEs are

particularly suited to the examination of ISAN relational embeddedness (Oehme and Bort, 2015; Prashantham and Birkinshaw, 2020). In particular, partner closeness in ISAN relational embeddedness can unlock tacit knowledge and promote valuable information sharing, hence ensuring SME post-entry internationalisation commitment (Prashantham and Dhanaraj, 2015).

\section{SME post-entry internationalisation commitment}

The international entrepreneurship literature divides the internationalisation process into successive stages wherein firms increase their level of international involvement over time (Johanson and Wiedersheim-Paul, 1975). As argued by Jones and Coviello (2005: 7), "by definition, internationalisation behaviour takes place over time, manifests in a time sequence 
in which events occur". In particular, the pre- and post-entry stages of internationalisation are two key dimensions of SME international venturing (Freixanet and Renart, 2020; Sleuwaegen and Onkelinx, 2014). Although the post-entry stage is crucial for SME international development (Puthusserry et al., 2020b; Fariborzi and Keyhani, 2018), scholars have only recently started distinguishing between the two stages (Khan and Lew, 2018; Gerschewski et al., 2018). Although an extensive body of research has focussed on the rapid entry into distant markets (i.e., pre-entry), only limited scholarly efforts have been dedicated to the increase in internationalisation commitment that follows (i.e., post-entry) (Freixanet and Renart, 2020; Zahoor et al., 2020). Specifically, post-entry internationalisation commitment is related to the investment of tangible and intangible resources in international activities (Chetty et al., 2014; Dominguez and Mayrhofer, 2017). Those SMEs that commit to international markets at their inception can make better use of their resources, achieve fast growth, and gain better market positioning (Hilmersson and Johanson, 2016; Sleuwaegen and Onkelinx, 2014). Post-entry internationalisation commitment can lead to entrepreneurial behaviours and to the achievement of higher revenues (Xue et al., 2021). However, the complexity or difficulty involved in investing large amounts of resources can be associated with high failure rates in SME international venturing.

Indeed, Sleuwaegen and Onkelinx (2014: 109) contended that SMEs "show the smallest initial commitment but also the highest likelihood of withdrawal from export markets". SMEs can decide to internationalise rapidly after long periods of domestic focus, but they may then limit their post-entry internationalisation commitment due to their liability of foreignness, lack of preparation, managerial difficulties, and financial pressures (Dominguez and Mayrhofer, 2017). Consequently, a fundamental aspect of the internationalisation literature-how SMEs expand their post-entry internationalisation commitment—remains unclear, and our study was aimed at addressing it (see Table 1 for review of literature). This takes on specific importance in the case of SMEs, which need to dedicate significant time and resources to attract new customers and/or increase their international commitment by assimilating more knowledge and learning to reduce uncertainty (Puthusserry et al., 2020a).

Researchers have recognised that ISANs help SMEs to acquire the knowledge and promote the learning that are vital for their post-entry internationalisation commitment (Masiello and Izzo, 2019; Puthusserry et al., 2020b). However, ISANs present inherent risks linked to the opportunistic behaviours of partnering firms, which lead to alliance failures (Dong et al., 2015). As such, ISAN relational embeddedness - which is characterised by 
closeness and reciprocity_encourages interaction and fosters the transfer of "fine-grained" information and knowledge (Uzzi, 1997: 45). This is also vital in order to overcome the liabilities of smallness and foreignness of SMEs that enter into foreign markets, especially when these markets are characterised by complex infrastructure (Galkina and Chetty, 2015; Masiello and Izzo, 2019). These studies are, however, less clear about how ISAN relational embeddedness contributes to SME post-entry internationalisation commitment (Puthusserry et al., 2020b). To move beyond, our study links ISAN relational embeddedness with OSCs, which, in turn, promotes post-entry internationalisation commitment.

\section{$<$ Insert Table 1 about here $>$}

\section{Hypotheses}

\section{ISAN relational embeddedness and post-entry internationalisation commitment}

Although legal contracts explicate the boundaries of the signatories' commitment in a relationship (Cao and Lumineau, 2015), relationally embedded relationships go beyond. Particularly, the notion of ISAN relational embeddedness points to the free exchange of resources as an outcome of closeness and mutual gratification (Bermiss and Greenbaum, 2016). Therefore, SMEs with greater ISAN relational embeddedness have a higher likelihood of gaining access to knowledge, information, and other resources, and, consequently, to promote their post-entry internationalisation commitment (Soontornthum et al., 2020). From the relational aspect of interdependence, ISAN relational embeddedness develops familiarity, reliability, and, ultimately, dependability between distant partners (Menzies et al., 2020). Furthermore, relationships between highly committed international partners are conducive to high quality information (Uzzi, 1997); therefore, strongly connected partners are likely to learn from each other (Song et al., 2020). The knowledge available through ISAN relational embeddedness enables SMEs to better understand the foreign market environment and learn what is strategically feasible for them (Tasheva and Nielsen, 2020), which makes them more comfortable in committing resources during the post-entry stage (Puthusserry et al., 2020a).

In particular, in an international context characterised by significant uncertainty, SME reliance on ISAN — facilitated by relational embeddedness - may reduce the risks involved in post-entry internationalisation commitment. From the social perspective, ISAN relational embeddedness helps SMEs to develop legitimacy and credibility, and facilitates the development of the new capabilities (e.g., complementary assets, product quality) needed for post-entry internationalisation commitment ( $\mathrm{Lu}$ et al., 2018). ISAN relational embeddedness opens up new possibilities and channels for partnership development aimed at increasing the attractiveness of SMEs in international markets (Puthusserry et al., 2020b). As such, SME 
entry into new partnerships denotes a lower liability of outsidership and less difficulty in doing business abroad (Vahlne and Johanson, 2013), thereby promoting SME post-entry internationalisation commitment. Relational embeddedness can also enhance the chance of SMEs being matched with other firms possessing complementary assets, thereby encouraging the former to commit more resources to international markets (Laursen et al., 2012).

The discussion above suggests that ISAN relational embeddedness nurtures SMEs by providing them with various market information and knowledge, which is particularly relevant in the post-entry stage. More specifically, a higher level of ISAN relational embeddedness will lead SMEs to a higher post-entry internationalisation commitment.

H1. ISAN relational embeddedness positively affects SME post-entry internationalisation commitment.

\section{The mediating role of OSCs}

Beyond our contention that ISAN relational embeddedness has implications for post-entry internationalisation commitment, more clarity is needed on the 'black-box' of mechanisms through which these variables are related (Sedziniauskiene et al., 2019). This question is akin to one of the key ones in the strategic alliance and post-entry literature (Ibeh et al., 2018; Zahoor et al., 2020) — namely, what is the nature of the link between ISAN embeddedness and post-entry internationalisation? This question is particularly important because, in a rapidly changing environment, a partner's knowledge can quickly become obsolete or valueless (Wohlgemuth and Wenzel, 2016). To respond to changes effectively, SMEs need to be able to effectively and efficiently transform their external knowledge (Teece, 2007; Nayak et al., 2020). As such, Al-Aali and Teece (2014: 107) argued the importance of OSCs, manifesting them as the "identification and assessment of opportunities at home and abroad" across upstream technological and downstream market domains. In our study, we maintain that ISAN relational embeddedness engenders post-entry internationalisation commitment through OSCs.

OSCs not only involve a firm's ability to identify upstream technological possibilities in the wavering global environment, but also concern the understanding of downstream market opportunities. Furthermore, a firm can sense upstream technological opportunities while simultaneously investigating downstream market needs, gaining the ability to develop innovations and thereby promoting a superior competitive advantage in foreign markets (Teece, 2007; Teece, 2014a). The international entrepreneurship literature asserts that OSCs enable SMEs to identify opportunities in other countries, whether for upstream technology advancement or for downstream market exploitation (Al-Aali and Teece, 2014). SMEs with 
OSCs are likely to be eminently alert and possess the ability to connect foreign market experiences and trends (Eisenhardt and Martin, 2000). Thus, opportunity-sensing is one of the core dynamic capabilities that enable firms to recognise complementary resources-i.e., a resource-picking mechanism - and combine them with their internal resource/knowledge base - i.e., a capability-building mechanism (see Eisenhardt and Martin, 2000; Fang and Zou, 2009) - to enhance post-entry internationalisation commitment (Vahlne and Johanson, 2017; Teece, 2014a).

In regard to OSCs as a mediating mechanism, prior research suggests that the mere possession of resources lacks effectiveness without the dynamic capabilities needed to realise their latent value (Teece, 2007). We therefore argued that OSCs mediate between ISAN relational embeddedness and post-entry internationalisation commitment. From the social perspective, SMEs can counteract their internal resource deficiency by exploiting their partners' complementary resources, thereby bolstering their ability to achieve the desired outcomes (Inkpen and Tsang, 2005). By synergically combining their partners' resources with their own, SMEs can acquire unique and difficult to imitate competencies (Dong et al., 2019; Donada et al., 2015). Accordingly, we argued that the maintenance of ISAN relational embeddedness is a solid foundation for the integration of complementary assets (Alinaghian et al., 2020), which can counteract SMEs' internal resource deficits and generate new functions from the existing ones, ultimately playing a vital role in promoting OSCs (Teece et al., 1997). As a result, due to their ability to identify options in the competitive markets, OSCs establish a sound basis for SMEs to achieve post-entry internationalisation commitment (Teece, 2007).

Specifically, given their relative lack of knowledge and resource bases-compared, for instance, to resource-abundant large multinationals-ISAN relational embeddedness is critical for internationalising SMEs to build and refresh their OSCs (Khan and Lew, 2018; Su et al., 2020). Furthermore, SMEs engaged in highly embedded relationships will be capable of engaging in vicarious and congenial learning from network partners (Puthusserry et al., 2020a). This creates a shared understanding of behaviours, enables mutual adaptation processes for resource exchange (Alinaghian et al., 2020), and consequently supports OSCs. Moreover, a strong emotional attachment broadens the range of topics discussed, which influences OSCs by increasing the acquisition and assimilation of knowledge beyond the existing stocks found within SME boundaries, thereby providing new business opportunities (Yoo et al., 2016; Zhang and Wu, 2017). Particularly, in an atmosphere of intimacy, ISAN partners can share information freely, being assured that they do not need to protect 
themselves from the opportunistic behaviours of others (Chung and Luo, 2013). In other words, high levels of relational embeddedness in quasi-hierarchical modalities - such as international alliances-reduce the transaction costs of network partnerships (Lew and Sinkovics, 2013).

Mutual understanding increases with the level of intimacy among partners, thus providing an effective channel for OSCs (Masiello and Izzo, 2019). ISAN relational embeddedness helps SMEs to develop various types of social capital through the creation of linkages (Coviello and Cox, 2006), which heightens their abilities to sense new technological upstream opportunities (e.g., technological knowledge and skills and product development) and market-related downstream ones (e.g., market development, market knowledge, commercialization, sales, and marketing).

SMEs possessing well-developed OSCs will aggressively explore innovations (Giudici et al., 2017; Koryak et al., 2015) by introducing new attributes to their upstream technology- and downstream market-related business activities (Johannessen et al., 2001; Prajogo et al., 2008). Moreover, with increasing involvement in foreign markets, OSCs intensify a firm's efforts to seek and attain new knowledge of market conditions and customer demands (Giudici et al., 2017). Accordingly, the knowledge so acquired can act as a resource suited to coordinate upstream technology- and downstream market-related business activities (Vahlne and Johanson, 2017), resulting in the achievement of higher post-entry internationalisation commitment by SMEs.

Taken together, the quickness and activeness inherent in OSCs enable SMEs to remain attentive to any emerging technology and market options in international markets, ultimately enabling them to choose the most appropriate opportunities (Weerawardena et al., 2019). OSCs enable a fit between SMEs' resources and new market opportunities, thereby facilitating the realisation of the values underlying the relational embeddedness resources. Furthermore, the flexibility inherent in OSCs creates a link between firm offerings and international market demands (Miocevic and Morgan Robert, 2018). This accommodates effective market and organisational learning (Park et al., 2020), which translates the benefits associated with ISAN relational embeddedness into post-entry internationalisation commitment (Khan and Lew, 2018). Stated differently, OSCs act as a paramount mechanism that enables SMEs to transform the latent value of ISAN relational embeddedness into postentry internationalisation commitment.

H2. OSCs mediate the relationship between ISAN relational embeddedness and postentry internationalisation commitment. 


\section{The moderating role of strategic adaptiveness}

Strategic adaptiveness is a firm's ability to strategically counter any challenges caused by foreign market idiosyncrasies (Hollender et al., 2017). It is regarded as a vital capability in today's dynamic and globalised business environment (Nyuur et al., 2016). Strategic adaptiveness is particularly relevant for resource-constrained SMEs because it can enable them to fully exploit their flexibility advantage when operating in dynamic environments characterised by intense competition, demanding customers, and technological sophistication (Nyuur et al., 2018). In an attempt to illustrate the direct effects of strategic adaptiveness, earlier studies have drawn on the institutional perspective and argued that adaptation of marketing practices and product offerings in accordance with foreign market norms is necessary to ensure firm legitimacy and make international gains (Brouthers et al., 2013; Sasaki et al., 2020). Other scholars contend for a contingency perspective of matching organisational resources with strategic adaptation to achieve internationalisation performance (Hollender et al., 2017; Mallett et al., 2019). To advance this line of research, we asserted that strategic adaptiveness is an important contingency factor suited to strengthen the influence of OSCs on post-entry internationalisation commitment. To counter SMEs' lack of foreign market knowledge, OSCs enable the better identification of market opportunities, whereas strategic adaptiveness facilitates the prompt tailoring of products and marketing practices to meet international market needs, thereby prompting post-entry internationalisation commitment. In this regard, strategic adaptiveness is a form of flexibility; a complementary dynamic capability (Eisenhardt and Martin, 2000) suited to overcome inertia and to quickly respond to varying contexts through the adaptation of competencies (Zhang et al., 2019).

When products and marketing practices are launched in international markets, foreign customers and buyers may misconstrue them and eventually fail to appreciate them due to differences in demands and preferences. As a countermeasure, strategic adaptiveness enables SMEs to meet the global demands of different groups by flexibly altering their products and marketing practices regardless of their lack of knowledge of foreign markets. This rationale was supported by Hollender et al. (2017), who suggested that product adaptation is a vital capability in dealing with any significant taste differences between foreign and domestic customers. However, strategic adaptiveness - e.g., changes in marketing practices to adapt to foreign markets - does not work in a vacuum (Sasaki et al., 2020). Rather, OSCs are vital to identifying opportunities and learning about the actions of other firms and their consequences (Surdu et al., 2020). This hints at the relevance of combining OSCs with strategic adaptiveness. While OSCs may enable SMEs to learn about which changes could lead to 
positive market consequences, strategic adaptiveness facilitates actual product and marketing localisation based upon the varied local requirements in heterogeneous foreign markets (Zhang et al., 2019). Thus, with increased strategic adaptiveness, SMEs could better exploit the OSCs for their post-entry internationalisation commitment.

OSCs are necessary to identify any opportunities and threats found in the external environment (Teece, 2014b), whereas strategic adaptiveness enables SMEs to strategically reduce their vulnerability to international market challenges (Zhang et al., 2019). SMEs utilise their OSCs to identify foreign market condition fluctuations and use the flexibility advantage conferred by strategic adaptiveness to localise their products, thereby quickly responding to environmental challenges (Un and Rodríguez, 2018; Johnson et al., 2013). Notably, strategic adaptiveness opportunities enable SMEs to fully exploit their OSCs because product and marketing practices can be adapted in response to the proactive identification of opportunities (Boojihawon et al., 2020; Miocevic and Morgan, 2018), therefore promoting post-entry internationalisation commitment. At low levels of strategic adaptiveness, SMEs can only make minor changes to their products and/or market practices in response to foreign market opportunities and threats; conversely, at high levels, SMEs can offer high-quality innovative products and refine their marketing practices to suit international markets.

H3. Strategic adaptiveness moderates the relationship between OSCs and post-entry internationalisation commitment.

Figure 1 provides this study's conceptual framework, which indicates that ISAN relational embeddedness affects OSCs, and ultimately leads to effective post-entry internationalisation commitment. It further proposes that the relationship between OSCs and post-entry internationalisation commitment is moderated by strategic adaptiveness.

\section{$<$ Insert Figure 1 here $>$}

\section{Methods}

\section{Research setting}

Our study was focussed on UK SMEs for two reasons. First, the business landscape of the UK is dominated by SMEs — which account for six million businesses $(99.9 \%$ of the business population) (FSB, 2020). SMEs are major contributors to the UK's job creation (60\% of the country's total employment), economic growth (49.8\%) and gross domestic product (DBEIS, 2020). Accordingly, international business research will benefit from understanding how UK SMEs - with their superlative impact on economic growth - achieve high performance after 
entering into international markets. Second, the UK is characterised by an open market economy, with liberal trade policies and favourable political conditions that have resulted in growing internationalisation activities (Bagheri et al., 2019; Stoian et al., 2018). For example, around $22.4 \%$ of UK SMEs are currently internationalised, with $17.3 \%$ engaging in frequent international activities and the remaining 5.1\% in occasional ones (Love et al., 2016). Due to the contributions made by UK SMEs and the country's economic situation, we deemed it appropriate to test our study's conceptual framework in that research setting.

\section{Sample and data collection}

Our survey data were drawn from SMEs operating in various manufacturing industries. We developed our sampling frame from the Financial Made It Easy (FAME) database. Following previous research (Boso et al., 2016; Wiklund and Shepherd, 2011), we adopted the following criteria to select our sample: 1) firms that were independent entities and not part of larger groups; 2) firms with fewer than 250 employees (classified as SMEs according to the European Union definition); 3) manufacturing firms engaged in international market activities; and 4) firms with complete contact information for their top executives or senior managers. Based on these criteria, 1,200 SMEs qualified for our study.

We designed a questionnaire and distributed it online to our sample SMEs through the Qualtrics platform. Our targeted respondents were owners, top executives, and senior managers (e.g., marketing managers and export managers). The definition of ISAN was presented and the following screening question was included on the front page of the questionnaire: "Has your firm actively participated in international strategic alliances that involved the participation of external organisations, such as customers, suppliers, competitors, consulting firms, and universities?" (Yan and Wagner, 2017). Only those participants who responded affirmatively to the screening question were allowed to complete the questionnaire. To further ensure our respondents' competency level, we included questions related to 1) knowledge of the specified issues, and 2) confidence in answering the questions. Eventually, we received 320 usable responses, representing a $26.67 \%$ response rate $26.67 \%$.

Our sample firms operated in various industries, including pharmaceuticals, computing, medical instruments, machinery and equipment, chemicals, rubber, nuclear fuel, metal products, recycling, food products, and textiles. Most of these firms (53.1\%) operated in high-technology industries, and the remaining in the medium- (26.6\%) and low-technology industries (20.3\%). $51.2 \%$ of our respondents were top executives, and the remaining $48.8 \%$ senior managers. On average, the age of our sample firms was 20.14 years and they had 
engaged in international operations in about seven countries. Their employee numbers ranged from 9 to 250 , with an average of 89 .

\section{Bias testing}

Non-response bias was assessed by comparing the early and late response groups (Armstrong and Overton, 1977). The independent t-tests were performed on demographic variables (e.g., number of employees and firm age) and on the key variables of the study (e.g., relational embeddedness and downstream market sensing). The results did not suggest any significant difference between the two groups, thereby indicating that non-response bias was not an issue in our dataset (Armstrong and Overton, 1977).

Additionally, as our data were self-reported, we assessed whether common method variance (CMV) posed a threat. Following Podsakoff et al. (2003), we had adopted ex-ante procedures in the design of our questionnaire. These included: 1) assuring our participants of the confidentiality and anonymity of their responses; 2) counterbalancing the order of independent and dependent variables; 3) defining any unfamiliar terms; 4) keeping questions simple and concise; and 5) avoiding double-barrelled questions. Furthermore, we applied expost statistical remedies to control for CMV. Specifically, we estimated three competing confirmatory factory analysis (CFA) models. A method-only model (Model 1) wherein all items were loaded on a single latent construct: $(\chi 2 / \mathrm{DF}=1003.66 / 160=6.27, \mathrm{p}=0.000$; $\mathrm{NFI}=0.74 ; \mathrm{CFI}=0.77 ; \mathrm{RMSEA}=0.13 ; \mathrm{SRMR}=0.11$ ); a trait-only model (Model 2) whereby each item was loaded on its respective latent construct: $\left(\chi^{2} / \mathrm{DF}=165.24 / 139=1.19, \mathrm{p}=0.06\right.$; $\mathrm{NFI}=0.96 ; \mathrm{CFI}=0.99 ; \mathrm{RMSEA}=0.02 ; \mathrm{SRMR}=0.04$ ); and a method-trait model (Model 3) where a common factor was included, linking all the items in Model 2 $(\chi 2 / \mathrm{DF}=159.47 / 137=1.16, \mathrm{p}=0.09 ; \mathrm{NFI}=0.96 ; \mathrm{CFI}=0.99 ; \mathrm{RMSEA}=0.02 ; \mathrm{SRMR}=0.04)$. The comparison of our three competing models suggested that Model 2 and Model 3 were superior to Model 1, and that Model 3 was not significantly superior to Model 2. This suggested that CMV did not explain our study data, and we thus concluded that CMV was not a serious concern in our study.

\section{Measures}

Based on previous studies, we utilised multiple-item scales. All the items were measured on seven-point Likert scales. In order to gain feedback on the clarity and wording of the questionnaire, we piloted it with senior academics and SME managers in the UK manufacturing industry. The final questionnaire was designed based on their comments.

Relational embeddedness relates to "how well one knows others" (Moran, 2005: 1130), signalling the close and personal relationship between ISAN partners (Dong et al., 
2015). We operationalised this construct using four items adopted from Chien et al. (2012) and Rindfleisch and Moorman (2001). The respondents were asked to evaluate the nature of their relationship with their international alliance partners.

OSC refers to "the ability of a firm to sense and identify opportunities and options in its scanning, searching and exploring across technologies and markets" (Zhang and Wu, 2013: 539). It advances the understanding of the business landscape, enables the identification of potential opportunities at home and abroad (Teece, 2014b), and involves gathering and filtering "technological and market information" (Teece, 2007: 1326). Accordingly, we conceptualised it as a second-order construct consisting of two first-order dimensions: upstream technology-sensing capability and downstream market-sensing capability. We measured the former using a four-item scale adopted from Srinivasan et al. (2002), which assesses the extent to which SMEs understand any technological advancement that may affect their business. On the other hand, we measured the latter using a four-item scale adapted from Morgan et al. (2009) and related to the extent to which firms sense market trends in relation to customers, competitors, and channel members.

Strategic adaptiveness was conceptualised as the ability of SMEs to adapt to challenges stemming from foreign market changes (Hollender et al., 2017). Strategic adaptiveness was measured using a four-item scale adopted from Nyuur et al. (2016).

Post-entry internationalisation commitment concerned the investment of resources in international activities after the initial entry into foreign markets (Dominguez and Mayrhofer, 2017; Chetty et al., 2014; Hilmersson and Johanson, 2016). A four-scale item was adopted from Armario et al. (2008) and Khalid and Bhatti (2015). To ensure their focus on the postentry stage, the respondents were asked to evaluate the degree to which their firms had made investments during the first three years of initial international market entry, relative to their expectations (Knight and Cavusgil, 2004; Khalid and Bhatti, 2015).

To test for potential sources of heterogeneity in our sample, we included control variables. First, firm size was measured as the logarithm of the number of employees. Second, firm age was measured as the logarithm of the years since its founding. Third, concerning industry type identification, 1 represented high-tech, 2 medium-tech, and 3 lowtech firms. Fourth, international scope was controlled by using the logarithm of the number of countries in which each firm was selling its products. Finally, international experience was measured as the number of years of operation in international markets. 


\section{Model fit, reliability, and validity}

CFA was performed using the SPSS AMOS 26.0 software to assess the model fit, reliability, and validity of the multiple-item scales. Our six-factor measurement model fit the data well, with all indices meeting the criteria $\left(\chi^{2} / \mathrm{DF}=165.24 / 139=1.19, \mathrm{p}=0.06 ; \mathrm{NFI}=0.96 ; \mathrm{CFI}=0.99\right.$; $\mathrm{RMSEA}=0.02 ; \mathrm{SRMR}=0.04)$.

Next, we inspected composite reliability (CR), Cronbach's alpha (CA), and factor loadings. As reported in Table 2, CR and CA were found to exceed 0.70 for all six constructs (Bagozzi and Yi, 2012), indicating a high level of internal reliability of the measurement model. Moreover, the factor loadings for all items ranged between 0.72 and 0.87 , thus being above the 0.70 threshold that guarantees indicator reliability (Kline, 2015).

To assess convergent validity, we observed the factor loadings on their corresponding latent constructs and average variance extracted (AVE). First, the path coefficients from the latent constructs to their respective items were found to be statistically significant. Moreover, each item was found to load significantly on its respective latent construct. Second, AVE showed satisfactory values of 0.5 and above (see Table 2). Taken together, the results provided evidence of convergent validity.

Discriminant validity was assessed in two ways. First, the value of the squared AVE of each construct was compared with the corresponding inter-construct correlation (Fornell and Larcker, 1981). The results (Table 2) suggest that the squared AVE of each construct was considerably greater than the respective inter-construct correlations. Second, the procedure recommended by Bagozzi et al. (1991) and a nested model CFA were performed. Specifically, different pairs of constructs were tested in a series of two-factor models, constraining the correlation between factors to 1 and then freeing the constraint. The results of the Chi-square difference test showed that the values of chi-square were significantly lower for the unconstrained models. Together, the results supported the discriminant validity of each of the constructs. Table 3 displays the descriptive statistics and the correlations, which were only moderate.

\section{$<$ Insert Tables 2 and 3 about here $>$}

\section{Results}

\section{Hypotheses testing}

Prior to the interpretation of the hypothesised path coefficients, we assessed the significance of the overall model and determined the fit of the paths with the basic structure of the data. The results suggested a good structural model fit (see Table 2). Following this, we estimated 
a series of five structural models using the AMOS 26.0 software. Model 1 was assessed permitting the control variables and relational embeddedness to be non-zero. In Model 2, the control variables and direct path of relational embeddedness for post-entry internationalisation commitment were estimated. Then, Model 3 was assessed, estimating the control variables and OSC for post-entry internationalisation commitment. In Model 4, the control and all variables were added to assess the mediation effect. Finally, in Model 5, the control, main effects, and interaction variables were freely estimated.

The results of the structural model analysis are shown in Table 4. Our structural equation modelling (Table 4 and Model 2) revealed that ISAN relational embeddedness is positively and significantly related to post-entry internationalisation commitment $(\beta=0.20$; $p<0.001)$. Thus, H1 was supported.

To test H2 (the mediating role of OSC), we followed Baron and Kenny's (1986) technique. Model 2 supported the first condition of Baron and Kenny's (1986) approach, suggesting that ISAN relational embeddedness is positively and significantly related to postentry internationalisation commitment. Model 1 confirmed the second condition by highlighting the positive and significant effect of ISAN relational embeddedness on OSC $(\beta=0.63 ; p<0.001)$. Model 3 confirmed the positive and significant effect of OSC on postentry internationalisation commitment $(\beta=0.43 ; p<0.001)$.

Moreover, Model 4 tested Baron and Kenny's (1986) final condition. showing that the significant impact of ISAN relational embeddedness on post-entry internationalisation commitment vanishes $(\beta=-0.03 ; p>0.10)$ when OSC is included in the post-entry internationalisation commitment structural model. OSC still has a significant and positive effect on post-entry internationalisation commitment $(\beta=0.45, p<0.001)$. These results together affirm the mediating role of OSC, indicating support for $\mathrm{H} 2$.

$\mathrm{H} 3$ contended that strategic adaptiveness strengthens the positive effect of OSC on post-entry internationalisation commitment. The interaction term between OSC and strategic adaptiveness Model 5) was found to be significant and positive $(\beta=0.30, p<0.001)$, indicating that, as the level of strategic adaptiveness increases, the positive effect of OSC on post-entry internationalisation commitment becomes also increases, suggesting support for $\mathrm{H} 3$.

\section{$<$ Insert Table 4 about here $>$}

\section{Robustness checks}

The mediation and moderation effects were further analysed to confirm the results of the structural models. Specifically, to examine H2, which predicts the mediating effect of OSC, 
the bootstrapping technique was utilised in the PROCESS Macro with the Sobel test. As shown in Table 5, ISAN relational embeddedness was found to have a positive and significant effect on OSC $(\beta=0.39, p<0.001)$ and post-entry internationalisation commitment $(\beta=0.17, p<0.001)$. OSC was also found to be positively and significantly related to postentry internationalisation commitment $(\beta=0.48, p<0.001)$. Furthermore, the indirect effect was found to be 0.19 and the bootstrapped $95 \%$ confidence intervals did not cross 0 for the upper (UL) and lower limits (LL), thereby suggesting a mediation effect of OSC and supporting H2. Figure 2 illustrates that the direct effect of ISAN relational embeddedness on post-entry internationalisation commitment becomes insignificant $(\beta=0.03, p>0.10)$ when OSC is added as a mediator.

\section{$<$ Insert Table 5 about here $>$}

Further, our moderation analysis was confirmed using PROCESS Macro. The interaction term between OSC and strategic adaptiveness was found to be positively and significantly related to post-entry internationalisation commitment $(\beta=0.10, p<0.01)$. Furthermore, the results in Table 5 shows that the effect of OSC on post-entry internationalisation commitment is stronger at high levels of strategic adaptiveness (effect=0.46; $\mathrm{LL}=0.28 ; \mathrm{UL}=0.64$ ), thus supporting $\mathrm{H} 3$. To further show the moderation effect, the interaction graph was plotted following Aiken et al.'s (2003) approach. Figure 3 graphically shows support for $\mathrm{H} 3$.

\section{$<$ Insert Figures 2 and 3 here $>$}

Moreover, to confirm the robustness of OSC as a second-order construct, we tested the individual effects of downstream market-sensing and upstream technology-sensing capabilities. The results suggested that post-entry internalisation commitment is determined by both downstream market-sensing $(\beta=0.29, \mathrm{p}<0.001)$ and upstream technology-sensing capabilities $(\beta=0.16, \mathrm{p}<0.01)$. A small effect of both downstream market-sensing $(f$ squared $=0.07)$ and upstream technology-sensing capabilities $(f$-squared $=0.04)$ on post-entry internalisation commitment was also found (Aiken et al., 2003). Also, the relationship between ISAN relational embeddedness and post-entry internationalisation commitment was found to be mediated by downstream market-sensing ( effect $=0.13 ; \mathrm{LL}=0.06 ; \mathrm{UL}=0.20$ ) and upstream technology-sensing capabilities (effect $=0.13 ; \mathrm{LL}=0.06 ; \mathrm{UL}=0.21$ ). However, our conceptualisation of OSC as a higher-order construct has much more explanatory power (effect=0.19; $\mathrm{LL}=0.11 ; \mathrm{UL}=0.27$ ) for its mediation of the relationship between ISAN relational embeddedness and post-entry internationalisation commitment. 


\section{Discussion and conclusion}

Evidence of post-entry internationalisation dynamics is drawing considerable attention from both scholars and managers, making it increasingly important for SMEs to establish that their early internationalisation efforts are balanced with their post-entry ones (Puthusserry et al., 2020a). While empirical studies have attempted to determine the antecedents of SME postentry internationalisation commitment (Puthusserry et al., 2020a), the findings have so far remained limited and inconclusive (Sleuwaegen and Onkelinx, 2014; Gerschewski et al., 2018). In this regard, our study proposed and validated the conceptual model in Figure 1, and its findings suggest that ISAN relational embeddedness is vital for SME post-entry internationalisation commitment. This finding is in line with those of prior studies, which suggested that ISAN relational embeddedness develops insidership to acquire foreign market information and reduce the risk of investing abroad, thereby driving international market venturing (Hennart et al., 2021; Gerschewski et al., 2015). Furthermore, our results confirm that OSC is an important mechanism through which ISAN relational embeddedness leads to increased post-entry internationalisation commitment. Trusting relationships with international partners engender in SMEs downstream market-sensing and upstream technology-sensing capabilities suited to identify opportunities and commit to post-entry internationalisation (Teece, 2014a; Alinaghian et al., 2020). In addition, we found that strategic adaptiveness strengthens the positive relationship between OSC and post-entry internationalisation commitment. Overall, our study findings extend the existing SME internationalisation literature to the domain of SME post-entry internationalisation commitment.

\section{Theoretical implications}

Our study contributes to the SME international and entrepreneurial literature in three ways. First, research on post-entry internationalisation commitment remains relatively scarce (Liedong et al., 2020; Fuentelsaz et al., 2020); thus, by integrating insights from the social perspective of SME internationalisation and entrepreneurship (Soontornthum et al., 2020; Menzies et al., 2020), our study shows that SME post-entry internationalisation commitment is largely shaped by ISAN relational embeddedness. Existing research has, to date, shown that ISANs are vital for SMEs to access the resources and knowledge possessed by their global partners (Forsgren, 2016; Lin et al., 2020). However, SMEs vary in their ability of attaining ISAN insidership (Johanson and Vahlne, 2009; Gerschewski et al., 2020) and also of building and securing legitimacy in ISANs at their post-entry internationalisation stage. In this regard, the extent to which close ISANs enable SMEs to realise knowledge benefits for 
post-entry internationalisation commitment has not yet been sufficiently explained. We therefore consider ISAN relational embeddedness both a social structure and a strategic resource suited to ensure that the relationships between SMEs and their international partners are high-quality, being based on mutual trust, solidarity, and reciprocity (Isaac et al., 2019; Liu et al., 2021). Such high-quality relationships stimulate the development of ISAN relational capital, which enables SMEs to request more tacit knowledge and collaborate over market information gathering, thereby leading to enhanced post-entry internationalisation commitment (Soontornthum et al., 2020; Puthusserry et al., 2020b). Thus, our study enriches the relational perspective on SME post-internationalisation research by demonstrating the importance of ISAN relational embeddedness for the post-entry internationalisation commitment of SMEs.

Second, our study helps to close the knowledge gap regarding the mediating mechanisms that connect ISAN relational embeddedness and SME post-entry internationalisation commitment. In this endeavour, we scrutinise the mediating role of OSC for ISAN relational embeddedness and SME post-entry internationalisation commitment relationships. As argued by Teece (2014b: 339), "while no firm will succeed forever in a particular market, strong dynamic capabilities allow a firm to ride successive waves of change across lines of business by renewing and leveraging their valuable and difficult-toreplicate resources for competitive advantage". Accordingly, we suggest OSCs as a mechanism through which SMEs "integrate, alter and deploy" ISAN relational embeddedness to pursue post-entry internationalisation commitment (Teece, 2014a: 17). Our results further suggest that market-sensing capabilities are more paramount than technologysensing ones in attaining SME post-entry internationalisation commitment. This finding corroborates the view that SMEs must possess market-specific knowledge to recognise international opportunities and develop new technologies to retain such opportunities (Xue et al., 2021). However, by combining these two capabilities, SMEs can attain higher benefits in international markets. These findings confirm that our study is an important extension of the dynamic capability and SME internationalisation literature because prior researchers had overlooked the linkage between ISAN relational embeddedness, OSC, and post-entry internationalisation outcomes (Zahoor et al., 2020). Thus, our study responds to the calls made by Khan and Lew (2018), Zahoor et al. (2020), and others to consider the social structures of ISANs and OSCs as important determinants of the achievement of post-entry internationalisation commitment. 
Third, our results explicitly define the conditions under which OSCs enhance postentry internationalisation efficacy. Although growing research on dynamic capabilities suggests their relevance for SME internationalisation (Buccieri et al., 2020), the issue of the possible interaction between capabilities for SME post-entry internationalisation commitment remains limited in the dynamic capabilities literature (Frasquet et al., 2018). Our study shows that SME strategic adaptiveness represents a crucial boundary condition for the effectiveness of OSCs in enabling post-entry internationalisation commitment. In doing so, it reveals that the relevance of OSCs for SME post-entry internationalisation commitment is driven by the extent to which they exploit strategic adaptiveness capabilities to improve learning and improve international commitment. In general, this is consistent with the viewpoint of Helfat and Peteraf (2015), suggesting that adaptiveness capability, underpinned by specific routines of alteration and strategic change, can be used in concert with other dynamic capabilities that enable reliable performance.

\section{Managerial implications}

Our findings have some practical implications. First, SME managers should be aware that their relationship with international partners is, in fact, an important channel for realizing their post-entry internationalisation commitment. Specifically, it is crucial for SMEs to invest socially (i.e., relational embeddedness) in ISANs in order to gain access to complementary knowledge and information necessary for successful innovation and market development in the post-entry stage. Therefore, SME managers should gain the trust of their partners to convert ISANs into cooperation networks involving the exchange of knowledge and information based on mutual adaptations. Such collaborative and adaptive partnerships would lead to unique commercial advantages and innovations conducive to post-entry internationalisation commitment. This is particularly relevant in the case of the UK, where the majority of firms are small. Due to the prevalence of intense competition between a large number of them, SMEs are forced to make efforts for post-entry internationalisation commitment to remain competitive; to this end, ISAN relational embeddedness, in the form of closer and mutually beneficial ties, is essential. However, too much trust can have a boomerang effect for SMEs, particularly in relationships with unsuitable partners. SMEs will be reluctant to monitor highly trusting relationships, which could lead to lower performance. As such, SME managers should avoid over-relying on trust, as this can inhibit access to various external sources of knowledge.

Second, SME managers should understand that current marketplaces are increasingly characterised by global competition, shorter product lifecycles, and market uncertainty, as in 
the case of the recent COVID-19 pandemic crisis and its disruption of global value chains. In such environments, managers should give special attention to OSCs in order to recognize technology and market changes ahead of competitors (Bharadwaj and Dong, 2014). OSCs yield continuous insights into the global market and technology trends that enable SMEs to respond by creating new resources or resource combinations. As shown in our study, ISAN relational embeddedness can serve as a building block of OSCs, as it provides access to complementary knowledge and resources and helps to identify opportunities. Once OSCs are nurtured, opportunities become more visible, enabling SMEs to move forward in committing to post-entry internationalisation. Thus, the managers of SMEs in international partnerships need to establish collaborative environments suited to promote relational quality for the development of OSCs and subsequent foreign market commitment, which can eventually lead to superior SME performance.

Third, SME managers would be advised to pay attention to strategic adaptiveness in their post-entry internationalisation endeavours. In particular, they should be aware that foreign market conditions and demands change over time. To turn these changes into favourable post-entry internationalisation commitment, managers should adapt their offerings to such changing conditions and demands. In particular, our findings suggest that managers should use OSCs and strategic adaptiveness simultaneously. While OSCs enable managers to identify changing trends, strategic adaptiveness facilitates the tailoring of SME offerings to them, ultimately leading to increased post-entry internationalisation commitment.

\section{Limitations and future research}

Our study has some limitations which point at fruitful avenues for future research. First, we only focussed on ISAN relational embeddedness as one of the relational mechanisms for post-entry internationalisation commitment. However, a more accurate understanding of the role played by relational factors in post-entry internationalisation commitment could be gained by extending the focus to other relational mechanisms - such as inter-firm commitment - and to how these interact with contractual governance mechanisms to predict the degree of post-entry internationalisation commitment. In a similar vein, our study does not entirely open the black-box of ISAN relational embeddedness. Future studies could scrutinize the level of ISAN embeddedness and explain its relevance for post-entry dynamics.

Second, future research could also investigate the relationships between OSCs, country risks and/or institutional environments, and post-entry internationalisation commitment. Prior research suggests that institutional support and barriers play an important role not only in strategic alliance capabilities, but also in SME performance in international 
markets (Torkkeli et al., 2019). Our results suggest that OSCs are likely to aid in the proactive identification of opportunities for post-entry internationalisation commitment. Further research could therefore examine the interplay between OSCs and institutional environment in relation to SME post-entry internationalisation commitment. Also, the influence of SME strategic adaptiveness on technology-sensing and market-sensing opportunities may differ in seizing such opportunities. Thus, future research could investigate the micro-foundations of sensing and seizing capabilities in the post-entry internationalisation process, and examine how contingency factors affect different elements of dynamic capabilities in the SME context.

Third, our study focussed on opportunity-sensing as an important aspect of dynamic capabilities. Future studies could consider other such capabilities, such as seizing, transforming, and realigning (Teece, 2007), and relate them to SME post-entry internationalisation commitment. Additionally, future studies could consider the relevance of organisational micro-foundations (e.g., leadership attributes and entrepreneurial decisionmaking for international network formation) for dynamic capabilities and their impact on post-entry internationalisation commitment.

Finally, the alliance formation and governance mechanisms of SMEs may differ from those of MNEs (O'Dwyer and Gilmore, 2018), potentially driving the post-entry internationalisation commitment of SMEs in a distinctive manner. As no data were collected from MNEs, it was impossible for us to compare our findings across SMEs and larger firms; future research could thus explore the ISAN relational embeddedness/post-entry internationalisation nexus through a sample involving both SMEs and MNEs.

\section{Conclusion}

In conclusion, drawing from ISAN relational embeddedness and dynamic capability perspectives, this study investigates how and to what extent SMEs can improve the post-entry internationalisation commitment. Our study findings demonstrate that ISAN relational embeddedness positively influences post-internationalisation commitment through SME OSC. Especially, strategic adaptiveness enhances the positive impact of SME OSC on postentry internationalisation commitment. Such key findings make important contributions to the SME's venturing and post-entry internationalisation literature. We hope that our study will encourage future research on different mediators and moderators of SME post-entry internationalisation commitment. 


\section{References}

Aiken LS, West SG and Pitts SC. (2003) Multiple linear regression. In: JA Schinka, WF Velicer and Weiner IB (eds) Handbook of Psychology. Canada: John Wiley \& Sons Inc.

Al-Aali A and Teece DJ. (2014) International entrepreneurship and the theory of the (longlived) international firm: a capabilities perspective. Entrepreneurship Theory and Practice 38: 95-116.

Alinaghian L, Kim Y and Srai J. (2020) A relational embeddedness perspective on dynamic capabilities: A grounded investigation of buyer-supplier routines. Industrial Marketing Management 85: 110-125.

Armario JM, Ruiz DM and Armario EM. (2008) Market orientation and internationalization in small and medium-sized enterprises. Journal of Small Business Management 46: 485-511.

Armstrong JS and Overton TS. (1977) Estimating nonresponse bias in mail surveys. Journal of Marketing Research 14: 396-402.

Bagheri M, Mitchelmore S, Bamiatzi V, et al. (2019) Internationalization Orientation in SMEs: The Mediating Role of Technological Innovation. Journal of International Management 25: 121-139.

Bagozzi RP and Yi Y. (2012) Specification, evaluation, and interpretation of structural equation models. Journal of the Academy of Marketing Science 40: 8-34.

Bagozzi RP, Yi Y and Phillips LW. (1991) Assessing construct validity in organizational research. Administrative Science Quarterly 36: 421-458.

Baron RM and Kenny DA. (1986) The moderator-mediator variable distinction in social psychological research: Conceptual, strategic, and statistical considerations. Journal of Personality and Social Psychology 51: 1173.

Bermiss YS and Greenbaum BE. (2016) Loyal to whom? The effect of relational embeddedness and managers' mobility on market tie dissolution. Administrative Science Quarterly 61: 254-290.

Bharadwaj N and Dong Y. (2014) Toward further understanding the market-sensing capability-value creation relationship. Journal of Product Innovation Management 31: 799-813.

Boojihawon DK, Richeri A, Liu Y, et al. (2020) Agile route-to-market distribution strategies in emerging markets: The case of Paraguay. Journal of International Management: 100740 .

Boso N, Story VM, Cadogan JW, et al. (2016) Enhancing the sales benefits of radical product innovativeness in internationalizing small and medium-sized enterprises. Journal of Business Research 69: 5040-5045.

Brouthers LE, O'Donnell E and Keig DL. (2013) Isomorphic pressures, peripheral product attributes and emerging market firm export performance. Management International Review 53: 687-710.

Buccieri D, Javalgi RG and Jancenelle VE. (2020) Dynamic capabilities and performance of emerging market international new ventures: Does international entrepreneurial culture matter? International Small Business Journal: 0266242620969682. 
Cao Z and Lumineau F. (2015) Revisiting the interplay between contractual and relational governance: A qualitative and meta-analytic investigation. Journal of Operations Management 33-34: 15-42.

Catanzaro A, Messeghem K and Sammut S. (2019) Effectiveness of export support programs: Impact on the relational capital and international performance of early internationalizing small businesses. Journal of Small Business Management 57: 436461.

Cavusgil ST and Knight G. (2015) The born global firm: An entrepreneurial and capabilities perspective on early and rapid internationalization. Journal of International Business Studies 46: 3-16.

Chetty S, Johanson M and Martín Martín O. (2014) Speed of internationalization: Conceptualization, measurement and validation. Journal of World Business 49: 633650 .

Chien S-H, Chen Y-H and Hsu C-Y. (2012) Exploring the impact of trust and relational embeddedness in e-marketplaces: An empirical study in Taiwan. Industrial Marketing Management 41: 460-468.

Chung CN and Luo XR. (2013) Leadership succession and firm performance in an emerging economy: Successor origin, relational embeddedness, and legitimacy. Strategic Management Journal 34: 338-357.

Ciabuschi F, Holm U and Martín Martín O. (2014) Dual embeddedness, influence and performance of innovating subsidiaries in the multinational corporation. International Business Review 23: 897-909.

Coviello NE and Cox MP. (2006) The resource dynamics of international new venture networks. Journal of International Entrepreneurship 4: 113-132.

Dasí À, Iborra M and Safón V. (2015) Beyond path dependence: Explorative orientation, slack resources, and managerial intentionality to internationalize in SMEs. International Business Review 24: 77-88.

DBEIS. (2020) Business population estimates for the UK and regions: 2019 statistical release (HTML). Available at: https://www.gov.uk/government/publications/businesspopulation-estimates-2019/business-population-estimates-for-the-uk-and-regions-

2019-statistical-release-

html\#: : text=SMEs\%20(small\%20and\%20medium $\% 2$ Dsized,million $\% 20 \mathrm{UK} \% 20$ pri vate $\% 20$ sector $\% 20$ businesses\&text $=$ there $\% 20$ were $\% 2035 \% 2 \mathrm{C} 600 \% 20$ medium $\% 2 \mathrm{Ds}$ ized,of $\% 20$ the $\% 20$ total $\% 20$ business $\% 20$ population.

Deschryvere M. (2014) R\&D, firm growth and the role of innovation persistence: an analysis of Finnish SMEs and large firms. Small Business Economics 43: 767-785.

Dimitratos P, Johnson JE, Plakoyiannaki E, et al. (2016) SME internationalization: How does the opportunity-based international entrepreneurial culture matter? International Business Review 25: 1211-1222.

Dominguez N and Mayrhofer U. (2017) Internationalization stages of traditional SMEs: Increasing, decreasing and re-increasing commitment to foreign markets. International Business Review 26: 1051-1063. 
Domurath A, Coviello N, Patzelt H, et al. (2020) New venture adaptation in international markets: A goal orientation theory perspective. Journal of World Business 55: 101019.

Donada C, Nogatchewsky G and Pezet A. (2015) Understanding the relational dynamic capability-building process. Strategic Organization 14: 93-117.

Dong MC, Liu Z, Yu Y, et al. (2015) Opportunism in Distribution Networks: The Role of Network Embeddedness and Dependence. Production and Operations Management 24: $1657-1670$.

Dong X, Zou S, Sun G, et al. (2019) Conditional effects of justice on instability in international joint ventures. Journal of Business Research 101: 171-182.

Ebers M and Maurer I. (2014) Connections count: How relational embeddedness and relational empowerment foster absorptive capacity. Research Policy 43: 318-332.

Eisenhardt KM and Martin JA. (2000) Dynamic capabilities: what are they? Strategic Management Journal 21: 1105-1121.

Fang EE and Zou S. (2009) Antecedents and consequences of marketing dynamic capabilities in international joint ventures. Journal of International Business Studies 40: 742-761.

Fariborzi H and Keyhani M. (2018) Internationalize to live: a study of the postinternationalization survival of new ventures. Small Business Economics 50: 607-624.

Fernhaber SA and Li D. (2013) International exposure through network relationships: Implications for new venture internationalization. Journal of Business Venturing 28: 316-334.

Ferraris A, Santoro G and Scuotto V. (2018) Dual relational embeddedness and knowledge transfer in European multinational corporations and subsidiaries. Journal of Knowledge Management 24: 519-533

Figueiredo PN. (2011) The role of dual embeddedness in the innovative performance of MNE subsidiaries: evidence from Brazil. Journal of Management Studies 48: 417-440.

Fornell C and Larcker DF. (1981) Evaluating structural equation models with unobservable variables and measurement error. Journal of Marketing Research 18: 39-50.

Forsgren M. (2016) A note on the revisited Uppsala internationalization process model - the implications of business networks and entrepreneurship. Journal of International Business Studies 47: 1135-1144.

Fraccastoro S, Gabrielsson M and Chetty S. (2021) Social media firm specific advantages as enablers of network embeddedness of international entrepreneurial ventures. Journal of World Business 56: 101164.

Frasquet M, Dawson J, Calderón H, et al. (2018) Integrating embeddedness with dynamic capabilities in the internationalisation of fashion retailers. International Business Review 27: 904-914.

Frasquet M, Dawson J and Mollá A. (2013) Post-entry internationalisation activity of retailers: An assessment of dynamic capabilities. Management Decision 51: 15101527.

Freixanet J and Renart G. (2020) A capabilities perspective on the joint effects of internationalization time, speed, geographic scope and managers' competencies on SME survival. Journal of World Business 55: 101110. 
FSB. (2020) UK Small Business Statistics. Available at: https://www.fsb.org.uk/uk-smallbusiness-statistics.html.

Fuentelsaz L, Garrido E and González M. (2020) Ownership in cross-border acquisitions and entry timing of the target firm. Journal of World Business 55: 101046.

Galkina T and Chetty S. (2015) Effectuation and networking of internationalizing SMEs. Management International Review 55: 647-676.

Gao H, Ren M, Zhang J, et al. (2016) Network gatekeeping in SME exporters' market entry in China. International Marketing Review 33: 276-297.

Gerschewski S. (2021) International opportunity development of born global firms: The role of institutions. Critical Perspectives on International Business: Forthcoming.

Gerschewski S, Evers N, Nguyen AT, et al. (2020) Trade shows and SME internationalisation: Networking for performance. Management International Review 60: 573-595.

Gerschewski S, Lew YK, Khan Z, et al. (2018) Post-entry performance of international new ventures: The mediating role of learning orientation. International Small Business Journal 36: 807-828.

Gerschewski S, Rose EL and Lindsay VJ. (2015) Understanding the drivers of international performance for born global firms: An integrated perspective. Journal of World Business 50: 558-575.

Giudici A, Reinmoeller P and Ravasi D. (2017) Open-system orchestration as a relational source of sensing capabilities: Evidence from a venture association. Academy of Management Journal 61: 1369-1402.

Gulati R. (1998) Alliances and networks. Strategic Management Journal 19: 293-317.

Helfat CE and Peteraf MA. (2015) Managerial cognitive capabilities and the microfoundations of dynamic capabilities. Strategic Management Journal 36: 831850.

Hennart J-F, Majocchi A and Hagen B. (2021) What's so special about born globals, their entrepreneurs or their business model? Journal of International Business Studies: 130 .

Hilmersson M and Johanson M. (2016) Speed of SME internationalization and performance. Management International Review 56: 67-94.

Hollender L, Zapkau FB and Schwens C. (2017) SME foreign market entry mode choice and foreign venture performance: The moderating effect of international experience and product adaptation. International Business Review 26: 250-263.

Hughes M, Cesinger B, Cheng C-F, et al. (2019) A configurational analysis of network and knowledge variables explaining Born Globals' and late internationalizing SMEs' international performance. Industrial Marketing Management 80: 172-187.

Ibeh K, Jones MV and Kuivalainen O. (2018) Consolidating and advancing knowledge on the post-entry performance of international new ventures. International Small Business Journal 36: 741-757.

Inkpen AC and Tsang EW. (2005) Social capital, networks, and knowledge transfer. Academy of Management Review 30: 146-165. 
Isaac VR, Borini FM, Raziq MM, et al. (2019) From local to global innovation: The role of subsidiaries' external relational embeddedness in an emerging market. International Business Review 28: 638-646.

Johannessen JA, Olsen B and Lumpkin GT. (2001) Innovation as newness: what is new, how new, and new to whom? European Journal of Innovation Management 4: 20-31

Johanson J and Vahlne J-E. (2009) The Uppsala internationalization process model revisited: From liability of foreignness to liability of outsidership. Journal of International Business Studies 40: 1411-1431.

Johanson J and Wiedersheim-Paul F. (1975) The internationalization of the firm: Four Swedish cases. Journal of Management Studies 12: 305-322.

Johnson JH, Arya B and Mirchandani DA. (2013) Global integration strategies of small and medium multinationals: Evidence from Taiwan. Journal of World Business 48: 47-57.

Jones MV and Coviello NE. (2005) Internationalisation: conceptualising an entrepreneurial process of behaviour in time. Journal of International Business Studies 36: 284-303.

Khalid S and Bhatti K. (2015) Entrepreneurial competence in managing partnerships and partnership knowledge exchange: Impact on performance differences in export expansion stages. Journal of World Business 50: 598-608.

Khan Z and Lew YK. (2018) Post-entry survival of developing economy international new ventures: A dynamic capability perspective. International Business Review 27: 149160.

Kline RB. (2015) Principles and practice of structural equation modeling. New York: Guilford publications.

Knight GA and Cavusgil ST. (2004) Innovation, organizational capabilities, and the bornglobal firm. Journal of International Business Studies 35: 124-141.

Knight GA and Liesch PW. (2016) Internationalization: From incremental to born global. Journal of World Business 51: 93-102.

Koryak O, Mole KF, Lockett A, et al. (2015) Entrepreneurial leadership, capabilities and firm growth. International Small Business Journal 33: 89-105.

Laursen K, Masciarelli F and Prencipe A. (2012) Trapped or spurred by the home region? The effects of potential social capital on involvement in foreign markets for goods and technology. Journal of International Business Studies 43: 783-807.

Lew YK and Sinkovics RR. (2013) Crossing borders and industry sectors: behavioral governance in strategic alliances and product innovation for competitive advantage. Long Range Planning 46: 13-38.

Lew YK, Sinkovics RR and Kuivalainen O. (2013) Upstream internationalization process: Roles of social capital in creating exploratory capability and market performance. International Business Review 22: 1101-1120.

Liedong TA, Peprah AA, Amartey AO, et al. (2020) Institutional voids and firms' resource commitment in emerging markets: A review and future research agenda. Journal of International Management 26: 100756.

Lin Z, Cao X and Cottam E. (2020) International networking and knowledge acquisition of Chinese SMEs: the role of global mind-set and international entrepreneurial orientation. Entrepreneurship \& Regional Development 32: 449-465. 
Liu G, Ko WW, Ngugi I, et al. (2021) Networking-bonding actions, quality of ties, and channel member collaboration: Evidence from U.K.-based small firms. Journal of Small Business Management 59: 13-46.

Love JH, Roper S and Zhou Y. (2016) Experience, age and exporting performance in UK SMEs. International Business Review 25: 806-819.

Lu JW, Song Y and Shan M. (2018) Social trust in subnational regions and foreign subsidiary performance: Evidence from foreign investments in China. Journal of International Business Studies 49: 761-773.

Mallett O, Wapshott R and Vorley T. (2019) How do regulations affect SMEs? A review of the qualitative evidence and a research agenda. International Journal of Management Reviews 21: 294-316.

Martineau C and Pastoriza D. (2016) International involvement of established SMEs: A systematic review of antecedents, outcomes and moderators. International Business Review 25: 458-470.

Masiello B and Izzo F. (2019) Interpersonal social networks and internationalization of traditional SMEs. Journal of Small Business Management 57: 658-691.

Masiello B, Izzo F and Canoro C. (2013) The structural, relational and cognitive configuration of innovation networks between SMEs and public research organisations. International Small Business Journal 33: 169-193.

Menzies J, Orr S and Paul J. (2020) SME internationalisation: The relationship between social capital and entry mode. Management International Review 60: 623-650.

Miocevic D and Morgan RE. (2018) Operational capabilities and entrepreneurial opportunities in emerging market firms: Explaining exporting SME growth. International Marketing Review 35: 320-341.

Moran P. (2005) Structural vs. relational embeddedness: social capital and managerial performance. Strategic management journal 26: 1129-1151.

Morgan NA, Slotegraaf RJ and Vorhies DW. (2009) Linking marketing capabilities with profit growth. International Journal of Research in Marketing 26: 284-293.

Nahapiet J and Ghoshal S. (1998) Social capital, intellectual capital, and the organizational advantage. Academy of Management Review 23: 242-266.

Nell PC and Ambos B. (2013) Parenting advantage in the MNC: An embeddedness perspective on the value added by headquarters. Strategic Management Journal 34: 1086-1103.

Nyuur RB, Brecic R and Y.A. D. (2018) SME international innovation and strategic adaptiveness: The role of domestic network density, centrality and informality. International Marketing Review 35: 280-300.

Nyuur RBbi, Brečić R and Simintiras A. (2016) The moderating effect of perceived effectiveness of SMEs' marketing function on the network ties-strategic adaptiveness relationship. Journal of Small Business Management 54: 1080-1098.

O'Dwyer M and Gilmore A. (2018) Value and alliance capability and the formation of strategic alliances in SMEs: The impact of customer orientation and resource optimisation. Journal of Business Research 87: 58-68. 
Oehme M and Bort S. (2015) SME internationalization modes in the German biotechnology industry: The influence of imitation, network position, and international experience. Journal of International Business Studies 46: 629-655.

Oehmichen J and Puck J. (2016) Embeddedness, ownership mode and dynamics, and the performance of MNE subsidiaries. Journal of International Management 22: 17-28.

Park JY, Muaid R, Lew YK, et al. (2020) Exploring the role of organizational learning and leadership in developing dynamic capabilities. European Journal of International Management: Forthcoming.

Petrou AP, Hadjielias E, Thanos IC, et al. (2020) Strategic decision-making processes, international environmental munificence and the accelerated internationalization of SMEs. International Business Review 29: 101735.

Podsakoff PM, MacKenzie SB, Lee J-Y, et al. (2003) Common method biases in behavioral research: a critical review of the literature and recommended remedies. Journal of Applied Psychology 88: 879-903.

Prajogo DI, McDermott P and Goh M. (2008) Impact of value chain activities on quality and innovation. International Journal of Operations \& Production Management 28: 615635

Prashantham S and Birkinshaw J. (2020) MNE-SME cooperation: An integrative framework. Journal of International Business Studies 51: 1161-1175.

Prashantham S and Dhanaraj C. (2015) MNE ties and new venture internationalization: Exploratory insights from India. Asia Pacific Journal of Management 32: 901-924.

Puthusserry P, Child J and Khan Z. (2020a) Social capital development through the stages of internationalization: Relations between British and Indian SMEs. Global Strategy Journal 10: 282-308.

Puthusserry P, Khan Z, Knight G, et al. (2020b) How do rapidly internationalizing SMEs learn? Exploring the link between network relationships, learning approaches and post-entry growth of rapidly internationalizing smes from emerging markets. Management International Review 60: 515-542.

Putzhammer M, Fainshmidt S, Puck J, et al. (2018) To elevate or to duplicate? Experiential learning, host-country institutions, and MNE post-entry commitment increase. Journal of World Business 53: 568-580.

Ren S, Fan D, Huang X, et al. (2021) The micro-foundation of ambidextrous opportunity identification in international expansion. International Business Review 30: 101764.

Rindfleisch A and Moorman C. (2001) The acquisition and utilization of information in new product alliances: A strength-of-ties perspective. Journal of marketing 65: 1-18.

Riviere M and Suder G. (2016) Perspectives on strategic internationalization: Developing capabilities for renewal. International Business Review 25: 847-858.

Rugman AM. (2014) Regional performance, multiple embeddedness and sustainability. Multinational Business Review 22.

Safari A and Chetty S. (2019) Multilevel psychic distance and its impact on SME internationalization. International Business Review 28: 754-765. 
Sanz-Blas S, Buzova D and Pérez-Ruiz P. (2021) Building relational worth in an online social community through virtual structural embeddedness and relational embeddedness. Technological Forecasting and Social Change 162: 120350.

Sasaki I, Nummela N and Ravasi D. (2020) Managing cultural specificity and cultural embeddedness when internationalizing: Cultural strategies of Japanese craft firms. Journal of International Business Studies: 1-37.

Sedziniauskiene R, Sekliuckiene J and Zucchella A. (2019) Networks' impact on the entrepreneurial internationalization: A literature review and research agenda. Management International Review 59: 779-823.

Sleuwaegen L and Onkelinx J. (2014) International commitment, post-entry growth and survival of international new ventures. Journal of Business Venturing 29: 106-120.

Song H, Yang X and Yu K. (2020) How do supply chain network and SMEs' operational capabilities enhance working capital financing? An integrative signaling view. International Journal of Production Economics 220: 107447.

Soontornthum T, Cui L, Lu VN, et al. (2020) Enabling SMEs' learning from global value chains: Linking the logic of power and the logic of embeddedness of interfirm relations. Management International Review 60: 543-571.

Srinivasan R, Lilien GL and Rangaswamy A. (2002) Technological opportunism and radical technology adoption: An application to e-business. Journal of marketing 66: 47-60.

Stoian M-C, Dimitratos P and Plakoyiannaki E. (2018) SME internationalization beyond exporting: A knowledge-based perspective across managers and advisers. Journal of World Business 53: 768-779.

Su F, Khan Z, Kyu Lew Y, et al. (2020) Internationalization of Chinese SMEs: The role of networks and global value chains. BRQ Business Research Quarterly 23: 141-158.

Surdu I, Greve HR and Benito GRG. (2020) Back to basics: Behavioral theory and internationalization. Journal of International Business Studies 52: 1047-1068.

Tasheva S and Nielsen BB. (2020) The role of global dynamic managerial capability in the pursuit of international strategy and superior performance. Journal of International Business Studies : 1-20.

Teece DJ. (2007) Explicating dynamic capabilities: the nature and microfoundations of (sustainable) enterprise performance. Strategic Management Journal 28: 1319-1350.

Teece DJ. (2014a) A dynamic capabilities-based entrepreneurial theory of the multinational enterprise. Journal of International Business Studies 45: 8-37.

Teece DJ. (2014b) The foundations of enterprise performance: Dynamic and ordinary capabilities in an (economic) theory of firms. Academy of Management Perspectives 28: 328-352.

Teece DJ, Pisano G and Shuen A. (1997) Dynamic capabilities and strategic management. Strategic Management Journal 18: 509-533.

Torkkeli L, Kuivalainen O, Saarenketo S, et al. (2019) Institutional environment and network competence in successful SME internationalisation. International Marketing Review 36: 31-55.

Tsai W and Ghoshal S. (1998) Social capital and value creation: the role of intrafirm networks. Academy of Management Journal 41: 464-476. 
Un CA and Rodríguez A. (2018) Local and global knowledge complementarity: R\&D collaborations and innovation of foreign and domestic firms. Journal of International Management 24: 137-152.

Uzzi B. (1997) Social structure and competition in interfirm networks: The paradox of embeddedness. Administrative Science Quarterly 41: 35-67.

Vahlne J-E and Johanson J. (2013) The Uppsala model on evolution of the multinational business enterprise-from internalization to coordination of networks. International Marketing Review 30: 189-210.

Vahlne J-E and Johanson J. (2017) From internationalization to evolution: The Uppsala model at 40 years. Journal of International Business Studies 48: 1087-1102.

Weerawardena J, Mort GS and Liesch PW. (2019) Capabilities development and deployment activities in born global B-to-B firms for early entry into international markets. Industrial Marketing Management 78: 122-136.

Wiklund J and Shepherd DA. (2011) Where to from here? EO-as-experimentation, failure, and distribution of outcomes. Entrepreneurship Theory and Practice 35: 925-946.

Xue R, Qian G, Qian Z, et al. (2021) Entrepreneurs' implicit and explicit achievement motives and their early international commitment. Management International Review 61: $91-121$.

Yan T and Wagner SM. (2017) Do what and with whom? Value creation and appropriation in inter-organizational new product development projects. International Journal of Production Economics 191: 1-14.

Yoo $\mathrm{Sj}$, Sawyerr O and Tan Wl. (2016) the mediating effect of absorptive capacity and relational capital in alliance learning of SMEs. Journal of Small Business Management 54: 234-255.

Zahoor N, Al-Tabbaa O, Khan Z, et al. (2020) Collaboration and Internationalization of SMEs: Insights and Recommendations from a Systematic Review. International Journal of Management Reviews 22: 427-456.

Zhang J, Jiang H, Wu R, et al. (2018) reconciling the dilemma of knowledge sharing: A network pluralism framework of firms' R\&D alliance network and innovation performance. Journal of Management 45: 2635-2665.

Zhang J and Wu W-P. (2013) Social capital and new product development outcomes: The mediating role of sensing capability in Chinese high-tech firms. Journal of World Business 48: 539-548.

Zhang J and Wu W-P. (2017) Leveraging internal resources and external business networks for new product success: A dynamic capabilities perspective. Industrial Marketing Management 61: 170-181.

Zhang X, Xie L, Li J, et al. (2019) “Outside in”: Global demand heterogeneity and dynamic capabilities of multinational enterprises. Journal of International Business Studies: 114. 


\section{Tables and Figures}

Table 1 Overview of the post-entry internationalisation efficacy research and of the contributions of our study

\begin{tabular}{|c|c|c|c|c|}
\hline \multicolumn{3}{|c|}{$\begin{array}{l}\text { Previous research related to post-entry } \\
\text { internationalisation efficacy }\end{array}$} & \multicolumn{2}{|c|}{ This study } \\
\hline $\begin{array}{l}\text { Research } \\
\text { stream }\end{array}$ & Key studies & $\begin{array}{l}\text { Selective research } \\
\text { insights }\end{array}$ & $\begin{array}{l}\text { Research gaps filled } \\
\text { by this study }\end{array}$ & $\begin{array}{l}\text { Key contributions of } \\
\text { our study }\end{array}$ \\
\hline $\begin{array}{l}\text { International } \\
\text { strategic } \\
\text { alliances }\end{array}$ & $\begin{array}{l}\text { Gerschewski et al. } \\
\text { (2018), } \\
\text { Puthusserry et al. } \\
\text { (2020b), } \\
\text { Puthusserry et al. } \\
\text { (2020a), and } \\
\text { Masiello and Izzo } \\
\text { (2019) }\end{array}$ & $\begin{array}{l}\text { ISANs are vital for } \\
\text { rapidly } \\
\text { internationalising } \\
\text { SMEs as they } \\
\text { provide useful } \\
\text { insights from } \\
\text { international experts. }\end{array}$ & $\begin{array}{l}\text { Prior studies lack } \\
\text { clarity regarding the } \\
\text { relational mechanisms } \\
\text { that enable the } \\
\text { exploitation of ISANs } \\
\text { for post-entry resource } \\
\text { commitment to forging } \\
\text { markets. }\end{array}$ & $\begin{array}{l}\text { To determine the } \\
\text { applicability of } \\
\text { strategies alliances by } \\
\text { considering ISAN } \\
\text { relational } \\
\text { embeddedness as a } \\
\text { determinant of the post- } \\
\text { internationalisation } \\
\text { commitment of SMEs. }\end{array}$ \\
\hline OSCs & $\begin{array}{l}\text { Frasquet et al., } \\
\text { (2013) and Khan } \\
\text { and Lew (2018) }\end{array}$ & $\begin{array}{l}\text { Opportunity-sensing, } \\
\text { as a specific dynamic } \\
\text { capability, is } \\
\text { essential to identify } \\
\text { the opportunities and } \\
\text { threats present in } \\
\text { foreign markets for } \\
\text { the post-entry } \\
\text { survival of firms. }\end{array}$ & $\begin{array}{l}\text { Prior SME research is } \\
\text { limited in terms of the } \\
\text { understanding of the } \\
\text { correlation between } \\
\text { ISAN relational } \\
\text { embeddedness, OSCs, } \\
\text { and post- } \\
\text { internationalisation } \\
\text { commitment. }\end{array}$ & $\begin{array}{l}\text { Explaining the relative } \\
\text { importance of ISAN } \\
\text { relational } \\
\text { embeddedness in } \\
\text { developing OSCs for } \\
\text { post- } \\
\text { internationalisation } \\
\text { commitment. }\end{array}$ \\
\hline $\begin{array}{l}\text { Strategic } \\
\text { adaptation }\end{array}$ & $\begin{array}{l}\text { Puthusserry et al. } \\
\text { (2020b), Khan and } \\
\text { Lew (2018), and } \\
\text { Safari and Chetty } \\
\text { (2019) }\end{array}$ & $\begin{array}{l}\text { SMEs can achieve } \\
\text { post-entry market } \\
\text { success by flexibly } \\
\text { adapting their } \\
\text { approaches in } \\
\text { foreign markets. }\end{array}$ & $\begin{array}{l}\text { Prior SME research } \\
\text { underestimates the role } \\
\text { played by adaptation } \\
\text { capability in adjusting } \\
\text { to the different } \\
\text { international } \\
\text { environments. } \\
\text { However, there is a } \\
\text { lack of evidence in } \\
\text { regard to the relations } \\
\text { between SMEs' sensing } \\
\text { and adaptation } \\
\text { capabilities. }\end{array}$ & $\begin{array}{l}\text { Providing new insights } \\
\text { by offering an } \\
\text { understanding of the } \\
\text { moderating role played } \\
\text { by strategic adaption in } \\
\text { the relationship } \\
\text { between OSCs and } \\
\text { post- } \\
\text { internationalisation } \\
\text { commitment. }\end{array}$ \\
\hline
\end{tabular}


Table 2 Constructs, measurement items, and reliability and validity tests

\section{Measures description and validation statistics}

SFL

Relational embeddedness (CA = 0.90; $C R=0.89 ; A V E=0.67)$

Please rate the degree to which the following items describe the nature of your firm's relationship with the other firms participating in international strategic alliances:

$\begin{array}{ll}\text { 1. We maintain close relationships with alliance partners. } & 0.79\end{array}$

2. Our relationship with alliance partners can be defined as "mutually 0.87 gratifying".

3. We expect that we will work with alliance partners far into the future. $\quad 0.84$

4. We feel indebted to our alliance partners for what they have done. 0.77

\section{Upstream technology-sensing capability $(C A=0.85 ; C R=0.87 ; A V E=0.63)$}

In regards to scanning, searching and exploring across technologies, please rate the degree to which your firm is capable of:

1. Detecting new technological developments that may potentially affect our $\quad 0.80$ business.

2. Seeking intelligence on technological changes in the environment that are $\quad 0.74$ likely to affect our business.

3. Rapidly sensing changes in technologies that might affect our business. $\quad 0.86$

4. Reviewing the key effect of changes in technology on our business.

Downstream market-sensing capability $(C A=0.84 ; C R=0.83 ; A V E=0.55)$

In regards to scanning, searching, and exploring across markets, please rate the degree to which your firm is capable of:

$\begin{array}{ll}\text { 1. Learning about customer needs and requirements. } & 0.72\end{array}$

2. Gaining insights about the channel. $\quad 0.72$

$\begin{array}{ll}\text { 3. Identifying and understanding market trends. } & 0.78\end{array}$

4. Learning about the broad market environment. 0.74

\section{Post-entry internationalisation commitment $(C A=0.86 ; C R=0.85 ; A V E=0.60)$}

Please rate the degree to which your firm made investments during the first three years of its initial entry in international markets in terms of:

$\begin{array}{ll}\text { 1. Devoting human resources to internationalisation training programmes. } & 0.74\end{array}$

2. Committing human resources to foreign market operations. 0.72

3. Implementing structural changes due to foreign market entry. 0.84

$\begin{array}{ll}\text { 4. Developing partnerships with international distributors and technology } & 0.77\end{array}$ partners due to foreign market entry.

\section{Strategic adaptiveness $(C A=0.89 ; C R=0.88 ; A V E=0.65)$}

Please rate the degree to which your firm has adapted its products or marketing strategy to international markets in comparison with competitors and in consideration of international customers' needs:

1. We adapt our marketing strategy adequately to changes in the business $\quad 0.76$ environment.

2. We adapt our marketing strategy adequately to changes in competitors' $\quad 0.82$ marketing strategies.

3. We adapt our products quickly to the changing needs of customers. $\quad 0.84$

4. We react quickly to market threats.

Fit indices: $\chi^{2} / \mathrm{DF}=165.24 / 139=1.19, \quad \mathrm{p}=0.06 ; \quad \mathrm{NFI}=0.96 ; \quad \mathrm{CFI}=0.99 ; \quad \mathrm{RMSEA}=0.02 ;$ $\mathrm{SRMR}=0.04$

Notes: $\mathrm{CA}=$ Cronbach's alpha; $\mathrm{CR}=$ composite reliability; $\mathrm{AVE}=$ average variance extracted; $\mathrm{SFL}=$ standardized factor loading. 
Table 3 Descriptive statistics and inter-construct correlations

\begin{tabular}{|c|c|c|c|c|c|c|c|c|c|c|c|c|}
\hline Variables & Mean & S.D. & 1 & 2 & 3 & 4 & 5 & 6 & 7 & 8 & 9 & 10 \\
\hline 1. Relational embeddedness & 5.10 & 1.37 & 0.82 & & & & & & & & & \\
\hline 2. Upstream technology sensing & 5.18 & 1.12 & $0.52^{* * *}$ & 0.79 & & & & & & & & \\
\hline 3. Downstream market sensing & 5.19 & 1.12 & $0.44^{* * *}$ & $0.55^{* * *}$ & 0.74 & & & & & & & \\
\hline 4. Post-entry internationalisation commitment & 4.93 & 1.15 & $0.20^{* * *}$ & $0.33^{* * *}$ & $0.38^{* * *}$ & 0.77 & & & & & & \\
\hline 5. Strategic adaptiveness & 4.97 & 1.29 & $0.32^{* * *}$ & $0.48^{* * *}$ & $0.57^{* * *}$ & $0.40^{* * *}$ & 0.81 & & & & & \\
\hline 6. Firm size & 1.78 & 0.42 & 0.02 & 0.06 & 0.02 & 0.07 & $0.11^{*}$ & 1.00 & & & & \\
\hline 7. Firm age & 1.12 & 0.37 & $-0.12^{*}$ & $-0.12^{*}$ & $-0.14^{*}$ & -0.03 & -0.07 & $0.16^{* *}$ & 1.00 & & & \\
\hline 8. Industry ${ }^{\#}$ & 2.20 & 3.27 & -0.01 & -0.04 & -0.01 & 0.00 & -0.01 & $0.12^{*}$ & 0.03 & 1.00 & & \\
\hline 9. International scope & 7.16 & 13.53 & -0.09 & -0.03 & -0.06 & 0.03 & 0.00 & 0.02 & 0.09 & -0.04 & 1.00 & \\
\hline 10. International experience & 0.57 & 0.48 & -0.05 & -0.08 & $-0.12^{*}$ & -0.05 & -0.07 & 0.07 & $0.64^{* * *}$ & 0.05 & -0.01 & 1.00 \\
\hline
\end{tabular}

Notes: Average variance extracted (AVE) is presented on the diagonal; S.D = standard deviation; significance levels: $\uparrow \mathrm{p}<0.10 ; * \mathrm{p}<0.05 ; * * \mathrm{p}<0.01 ; * * * \mathrm{p}<0.001$; * = natural logarithm; ${ }^{*}=$ dummy variables. 
Table 4 Results of direct, indirect and moderating effects

\begin{tabular}{|c|c|c|c|c|c|}
\hline \multirow{3}{*}{ Description } & \multicolumn{5}{|c|}{ Dependent variables } \\
\hline & \multirow{2}{*}{$\begin{array}{c}\text { OSC } \\
\text { Model } 1\end{array}$} & \multicolumn{4}{|c|}{ Post-entry internationalisation commitment } \\
\hline & & Model 2 & Model 3 & Model 4 & Model 5 \\
\hline \multicolumn{6}{|l|}{ Controls } \\
\hline Firm size & $0.04(0.66)$ & $0.02(0.26)$ & $-0.01(-0.07)$ & $-0.01(0.77)$ & $-0.03(-0.61)$ \\
\hline Firm age & $-0.05(-0.79)$ & $0.01(0.17)$ & $0.05(0.72)$ & $0.05(0.64)$ & $-0.01(-0.09)$ \\
\hline Industry & $-0.02(-0.03)$ & $0.01(0.11)$ & $0.02(0.31)$ & $0.03(0.45)$ & $0.03(0.58)$ \\
\hline International experience & $-0.05(-0.75)$ & $-0.05(-0.69)$ & $-0.02(-0.22)$ & $-0.01(-0.16)$ & $0.03(0.41)$ \\
\hline International scope & $0.01(0.10)$ & $0.05(0.87)$ & $0.06(1.11)$ & $0.05(0.87)$ & $0.06(1.12)$ \\
\hline \multicolumn{6}{|l|}{ Main Effects } \\
\hline Relational embeddedness & $0.63^{* * *}(8.52)$ & $0.20^{* * *}(3.37)$ & & $-0.03(-0.52)$ & \\
\hline OSC & & & $0.43^{* * *}(7.01)$ & $0.45^{* * *}(6.28)$ & $0.31^{* * *}(4.39)$ \\
\hline Strategic adaptiveness & & & & & $0.17^{*}(2.72)$ \\
\hline \multicolumn{6}{|l|}{ Interaction effect } \\
\hline OSC $\mathrm{x}$ Strategic adaptiveness & & & & & $0.30^{* * *}(4.32)$ \\
\hline \multicolumn{6}{|l|}{ Goodness-of-fit statistics } \\
\hline$\chi^{2}$ & 69.93 & 34.57 & 42.44 & 50.28 & 51.03 \\
\hline$\chi^{2 / D F}$ & 1.35 & 1.73 & 1.51 & 1.57 & 1.42 \\
\hline NFI & 0.96 & 0.96 & 0.96 & 0.95 & 0.96 \\
\hline CFI & 0.98 & 0.98 & 0.98 & 0.98 & 0.99 \\
\hline RMSEA & 0.03 & 0.05 & 0.04 & 0.04 & 0.04 \\
\hline SRMR & 0.03 & 0.02 & 0.03 & 0.03 & 0.03 \\
\hline
\end{tabular}


Table 5 Results of Sobel and bootstrapping tests

\begin{tabular}{|c|c|c|c|}
\hline Effects & Estimates & LL 95\% CI & UL $95 \%$ CI \\
\hline \multicolumn{4}{|c|}{ Mediation effect of OSC } \\
\hline Relational embeddedness $\rightarrow$ OSC & $0.39^{*}$ & 0.32 & 0.45 \\
\hline $\begin{array}{l}\text { Relational embeddedness } \rightarrow \text { Post-entry } \\
\text { internationalisation commitment }\end{array}$ & $0.17^{*}$ & 0.08 & 0.26 \\
\hline OSC $\rightarrow$ Post-entry internationalisation commitment & $0.48^{*}$ & 0.34 & 0.62 \\
\hline Indirect effect & $0.19^{*}$ & 0.11 & 0.27 \\
\hline Total effect & $0.17^{*}$ & 0.08 & 0.26 \\
\hline Sobel Z-value & $6.07^{* * *}$ & \multicolumn{2}{|c|}{ SE: 0.03} \\
\hline \multicolumn{4}{|c|}{ Moderation effect of strategic adaptiveness } \\
\hline -1 SD of strategic adaptiveness & 0.22 & 0.07 & 0.37 \\
\hline Mean of strategic adaptiveness & 0.34 & 0.19 & 0.49 \\
\hline$+1 \mathrm{SD}$ of strategic adaptiveness & 0.46 & 0.28 & 0.64 \\
\hline
\end{tabular}

Notes: "Indicates non-zero within the boundaries (significant); ${ }^{* * *}$ indicate $\mathrm{p}<0.001 ; \mathrm{SD}=$ standard deviation; $\mathrm{SE}=$ standard error; $\mathrm{CI}=$ confidence interval.

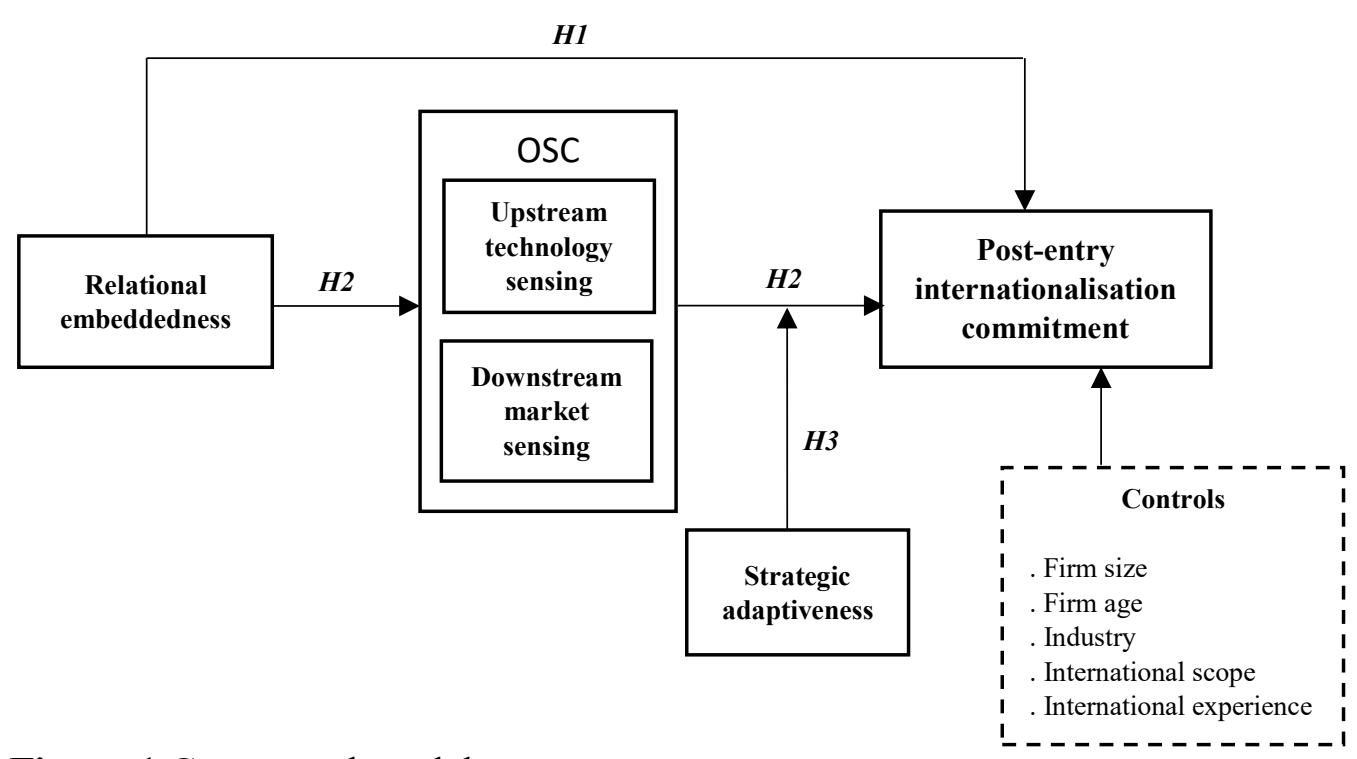

Figure 1 Conceptual model

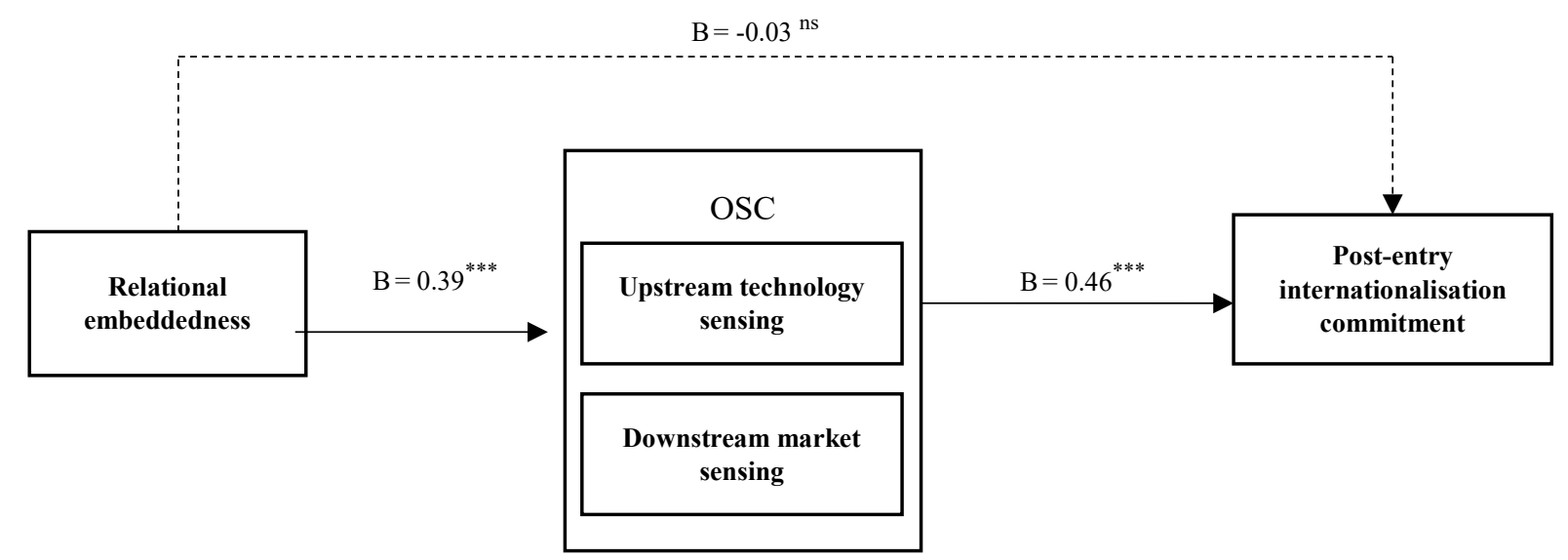

Notes: significance levels: $\dagger \mathrm{p}<0.10 ;{ }^{*} \mathrm{p}<0.05 ;{ }^{* *} \mathrm{p}<0.01 ;{ }^{* * *} \mathrm{p}<0.001 ;{ }^{\mathrm{ns}}=$ not significant.

Figure 2 Results of direct and indirect effects for mediation 


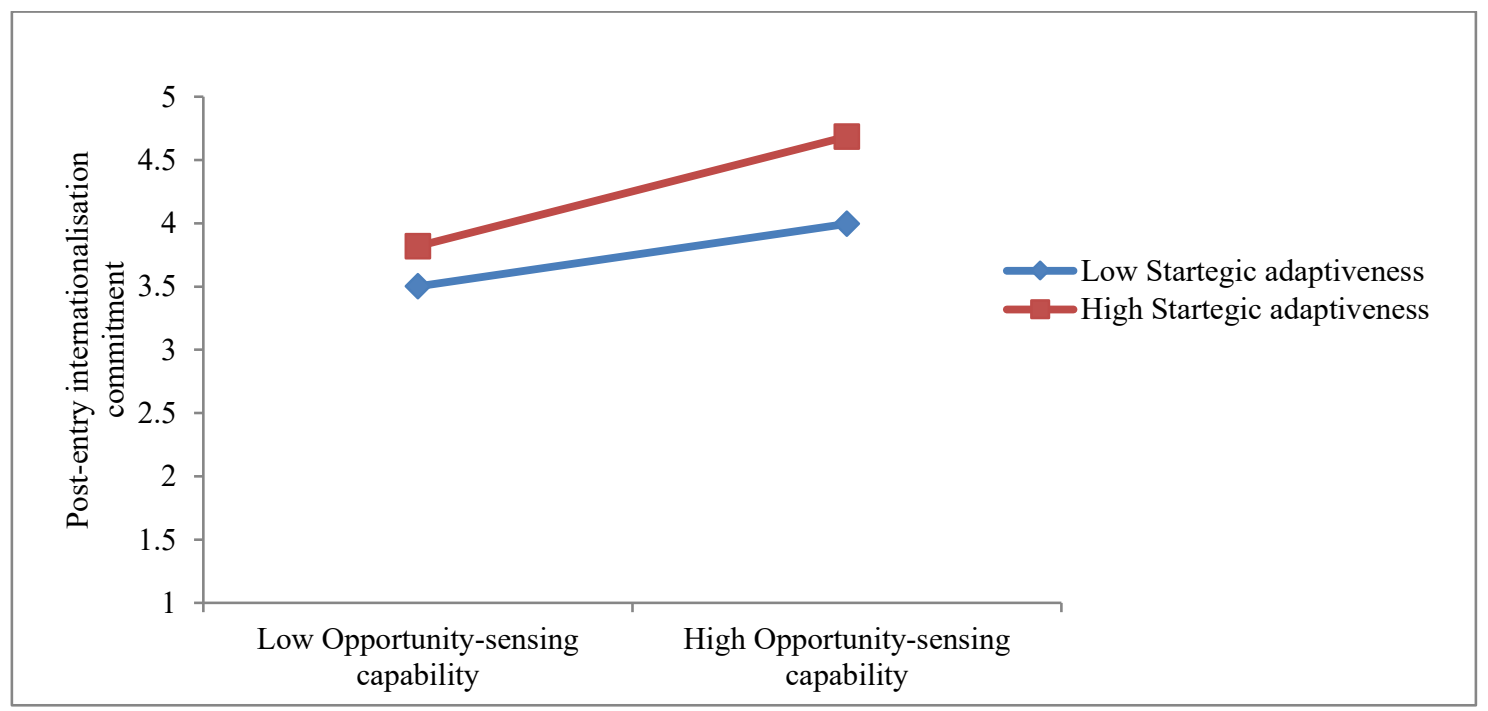

Figure 3 Moderating effect of strategic adaptiveness 